University of Nebraska - Lincoln

DigitalCommons@University of Nebraska - Lincoln

\title{
Genetic Diversity, Plant Adaptation Regions, and Gene Pools for Switchgrass
}

\author{
Michael D. Casler \\ USDA-ARS, michael.casler@ars.usda.gov \\ Chad A. Stendal \\ University of Wisconsin-Madison \\ Ludmila Kapich \\ University of Wisconsin-Madison \\ Kenneth P. Vogel \\ University of Nebraska-Lincoln, kvogel1@unl.edu
}

Follow this and additional works at: https://digitalcommons.unl.edu/usdaarsfacpub

Casler, Michael D.; Stendal, Chad A.; Kapich, Ludmila; and Vogel, Kenneth P., "Genetic Diversity, Plant Adaptation Regions, and Gene Pools for Switchgrass" (2007). Publications from USDA-ARS / UNL Faculty. 1939.

https://digitalcommons.unl.edu/usdaarsfacpub/1939

This Article is brought to you for free and open access by the U.S. Department of Agriculture: Agricultural Research Service, Lincoln, Nebraska at DigitalCommons@University of Nebraska - Lincoln. It has been accepted for inclusion in Publications from USDA-ARS / UNL Faculty by an authorized administrator of DigitalCommons@University of Nebraska - Lincoln. 


\title{
Genetic Diversity, Plant Adaptation Regions, and Gene Pools for Switchgrass
}

\author{
Michael D. Casler,` Chad A. Stendal, Ludmila Kapich, and Kenneth P. Vogel
}

\begin{abstract}
Switchgrass (Panicum virgatum L.) is a perennial grass native to the North American tallgrass prairie and broadly adapted to the central and eastern USA. Transfer of germplasm throughout this region creates the potential of contaminating local gene pools with genes that are not native to a locale. The objective of this study was to identify structural patterns and spatial variation for molecular markers of switchgrass populations from the northern and central USA. Fortysix prairie-remnant populations and 11 cultivars were analyzed for random amplified polymorphic DNA (RAPD) markers. Although there was significant population differentiation, little of this variation was associated with geographic regions. A small amount of population differentiation was associated with hardiness zones and ecoregions, suggesting that a recent proposal to use these two criteria for defining plant adaptation regions has merit for defining gene pools and seed-transfer zones of switchgrass. Cultivars of switchgrass cannot be differentiated from prairie-remnant populations in the northern and central USA on the basis of RAPD markers, indicating that they are still highly representative of natural germplasm. Seed sources of switchgrass can be moved considerable distance within hardiness zones and ecoregions without causing significant contamination, pollution, swamping, or erosion of local gene pools.
\end{abstract}

M.D. Casler, USDA-ARS, U.S. Dairy Forage Research Center, Madison, WI 53706-1108; C.A. Stendal and L. Kapich, Dep. of Agronomy, Univ. of Wisconsin, Madison, WI 53706; and K.P. Vogel, USDA-ARS, Univ. of Nebraska-East Campus, P.O. Box 830937, Lincoln, NE 68583-0937. Received 14 Dec. 2006. ${ }^{\star}$ Corresponding author (mdcasler@wisc.edu).

Abbreviations: PAR, plant adaptation region; PRP, prairie-remnant population; RAPD, random amplified polymorphic DNA; RGP, restoration gene pool.

Switchgrass (Panicum virgatum L.) is native to the tallgrass $S$ prairie of the central USA. It can be found in prairie remnants and under cultivation from the Rocky Mountains to the Atlantic Seaboard, from Nova Scotia to Florida, and from Saskatchewan to Arizona (Stubbendieck et al., 1991). Switchgrass is adapted to a wide range of habitats and ecosystems in eastern North America and is used for hay production, grazing, soil conservation, and prairie restoration (Vogel, 2004).

Some of these uses are potentially in conflict with each other. Hay fields, whether intended for livestock or bioenergy production, and pastures are generally established with seed of improved cultivars. Switchgrass cultivars derive from two sources: seed increases of accessions collected from prairie-remnant populations and populations created by selection and breeding (Alderson and Sharp, 1994). Prairie-remnant populations that bear a cultivar name represent a wide range of ecosystems east of the Rocky Mountains. These cultivars were not derived by selection and breeding and, to the extent that seed production is carefully controlled, directly represent natural switchgrass populations. Cultivars derived from selection and breeding largely originated from prairie-remnant populations of the Great Plains. Because

Published in Crop Sci. 47:2261-2273 (2007).

doi: 10.2135/cropsci2006.12.0797

(C) Crop Science Society of America

677 S. Segoe Rd., Madison, WI 53711 USA

All rights reserved. No part of this periodical may be reproduced or transmitted in any form or by any means, electronic or mechanical, including photocopying, recording, or any information storage and retrieval system, without permission in writing from the publisher. Permission for printing and for reprinting the material contained herein has been obtained by the publisher. 
switchgrass breeding did not begin in earnest until the last quarter of the 20th century and breeding cycles require many years, these cultivars are not far removed from wild populations of switchgrass (Alderson and Sharp, 1994; Vogel, 2004). Both types of named cultivars were released for certified seed production after extensive evaluation for persistence, forage yield, and other agronomic traits in their intended area of use. The purpose of the cultivar seed certification process is to maintain genetic integrity of the cultivars.

Restoration biologists usually prefer local germplasm for conservation and restoration, largely based on the assumption that local germplasm is better adapted than germplasm from other regions (Clewell and Rieger, 1997; Lesica and Allendorf, 1999; Montalvo et al., 1997). In some regions, this assumption has led to regulations stipulating the use of local germplasm (Clewell and Rieger, 1997; Jones, 2003, Rogers and Montalvo, 2004). Little or no testing of the germplasm is conducted and, consequently, the adaptation range of local germplasm is unknown. Prairie restoration and the use of native grasses for landscaping and conservation have become much more common in recent years, creating a need for scientific data on the importance of local populations, the geographic definition of local regions, and the genetic composition of local populations (Clewell and Rieger, 1997; Lesica and Allendorf, 1999; Montalvo et al., 1997). Local populations are often difficult to define (Rogers and Montalvo, 2004, p. 21), leading to potentially arbitrary boundaries.

Seed orchards, established from seed collected on prairie remnants, have been used as a long-term source of seed for conservation or restoration purposes within narrowly defined geographic regions. These seed populations are generally harvested or collected by hand and threshed and cleaned using fairly small-scale equipment. Due to narrowly defined geographic ranges and to the minimal use of mechanization for seed production and processing, seed prices of local accessions tend to be extremely high. In some cases, public agencies have taken on this responsibility to make these seed sources available for local landowners and public lands.

Conflict arises between these two uses because seed from cultivars or from prairie remnants outside of a small region are considered to be undesirable for conservation or restoration purposes. Conservationists criticize such germplasm as unacceptable because it contains genes and traits from other regions, it does not represent the local region either genetically or phenotypically, and it may lead to outbreeding depression and genetic pollution in local populations (Lesica and Allendorf, 1999; Montalvo et al., 1997). Because nothing is known about the genetic structure of prairie-remnant switchgrass populations, there is no scientific evidence to either support or refute this criticism. The potential consequences of gene flow from non- native germplasm into local germplasm pools are largely unknown (Rogers and Montalvo, 2004, p. 131).

The objective of this study was to identify structural patterns and spatial variation for molecular markers of switchgrass populations from the northern and central USA. The presence of structural patterns or spatial variation would indicate that these criticisms are well founded, that there are different switchgrass gene pools in different regions of the northern and eastern USA. The degree to which spatial patterns exist among prairie-remnant populations will partly determine the limits within which gene pools can be exchanged among regions without significantly contaminating local gene pools. Conversely, lack of spatial variation will suggest that these fears are unfounded for this species and local regions for conservation or restoration using switchgrass germplasm may be broader than perceived by many restoration biologists.

\section{MATERIALS AND METHODS}

A total of 78 switchgrass accessions were collected from 59 sites in Minnesota, Wisconsin, Michigan, Indiana, Ohio, and New York in 1997 and 1998 (Table 1). Sites were identified as prairie remnants based on local agency records. Some of the collection sites were sufficiently large or variable to prompt collection of multiple accessions from these sites. Multiple accessions were collected from a site when there was significant variability in soil type, aspect, or habitat within the site. Seeds were stored at room temperature until December 1998. A sample of seed of each accession was chilled at $3^{\circ} \mathrm{C}$ for $3 \mathrm{wk}$ and planted in plastic seedling tubes containing a 1:1 mixture of silt loam soil and peat moss. Seed dormancy problems limited the study to a total of 46 accessions from 34 sites (Fig. 1).

In January 1999, seedlings of 11 cultivated switchgrass populations ('Blackwell,' 'Cave-in-Rock,' 'Pathfinder,' 'Shawnee,' 'Shelter,' 'Summer,' 'Sunburst,' 'Trailblazer,' 'NE-HZ4,' 'NEearly-HYC3-HDC2,' and 'NE28-HYC3-HDC2') were germinated without prechilling (Table 1). The cultivars represented both seed increases from prairie remnants and the products of breeding programs (Alderson and Sharp, 1994). For most populations, 10 to 20 seedlings were used to represent each cultivar or prairie-remnant population; numbers $<20$ were due to reduced germination rates or seedling mortality (Table 1). A total of 818 seedlings were raised in the greenhouse for DNA extraction.

Genomic DNA was extracted from all plants. Fresh leaves (0.1-0.2 g) were macerated in potassium ethyl xanthogenate (PEX) DNA extraction buffer with a ceramic bead using a FastPrep FP120 machine (BIO 101 Inc., Carlsbad, CA). The remainder of the DNA extraction procedure followed Johns et al. (1997) with minor modification. The samples were ground in $450 \mu \mathrm{L}$ of DNA extraction buffer in $2.0-\mathrm{mL}$ microcentrifuge tubes. All remaining DNA extraction procedures were performed in $1.5-\mathrm{mL}$ microcentrifuge tubes.

Reactions for RAPD analysis were performed in $10-\mu \mathrm{L}$ volumes in 96-well plates in an MJ PTC-100 incubator (MJ Research, Watertown, MA) following the methods of Johns et al. (1997). Seven 10-mer primers (AB11, AB16, AC05, AC19, AD05, AD11, and AE4 from Operon Technologies, Huntsville, AL) were 
selected for this study because of the consistent clarity and reproducibility of polymorphic bands and polymorphisms on DNA samples of a subset of the 818 switchgrass plants. All RAPD reaction products were electrophoresed on agarose gels as described by Johns et al. (1997). Gels were run for $2 \mathrm{~h}$ at $300 \mathrm{~V}$, stained with ethidium bromide, illuminated by ultraviolet light, photographed, and manually scored for the presence or absence of clear bands. Polymorphic fragments, possessing unambiguous differences among the DNA samples and ranging from 0.2 to $2.1 \mathrm{~kb}$, were visually scored for the presence (1) or absence ( 0 ) of the band using a digital imaging and scoring system (Syngene digi-genius photo-documentation package, Cambridge, UK). A total of 125 polymorphic bands were scored.

Repeatability of the 125 polymorphic RAPD bands was evaluated by conducting an independent set of reactions on a subset of 48 plants, one random plant from each of 48 accessions or cultivars. All reaction and scoring conditions were identical to those described above, except that all operations were conducted by a different person, allowing an independent assessment of reaction and scoring results for each RAPD band. Repeatability was determined by counting the number of mismatches on 48 plants, separately for each of the 125 bands. A total of 119 bands met our minimum repeatability criterion of 46 or more "correct" or identical scores. The average error rate was 0.4 mismatches per band (0.8\%).

Genetic distances among the 818 plants in all pairwise combinations were estimated as the complement to Jaccard's similarity coefficient (Gower, 1972). The genetic distance matrix was characterized by two orthogonal coordinates using a multidimensional scaling procedure (PROC MDS, SAS Institute, 1999). Analysis of molecular variance (AMOVA; Excoffier et al., 2005) was performed on all individuals, partitioning the genetic distance matrix into seven sources of variation (Table 2). Variance components were estimated by equating AMOVA mean squares to their expectations and were tested by nonparametric permutation tests (Excoffier et al., 2005). Average marker diversity was computed for each cultivar using the formula of Nei (1987, p. 257). Cluster analysis, using the unweighted pair group method with arithmetic mean, was performed on the frequencies of each marker within each of the 46 prairie-remnant populations and 11 cultivars.

Genetic distances among the 46 prairie remnant populations in all pairwise
Table 1. Source information for 46 prairie-remnant populations and 11 cultivars of switchgrass analyzed for random amplified polymorphic DNA (RAPD) marker diversity, including number of plants analyzed $(n)$.

\begin{tabular}{|c|c|c|c|c|c|c|c|}
\hline $\begin{array}{l}\text { Accession no. } \\
\text { or cultivar name }\end{array}$ & Site & State & $n$ & Ecoregion ${ }^{\dagger}$ & $\begin{array}{l}\text { Hardiness } \\
\text { zone }\end{array}$ & Latitude & Longitude \\
\hline & & & & & & ${ }^{\circ} \mathrm{N}$ & ${ }^{\circ} \mathrm{W}$ \\
\hline WS97.01 & TP & Indiana & 3 & EBFC & 4 & 40.30 & 86.22 \\
\hline WS97.04 & HW1 & Indiana & 16 & GPS & 6 & 40.45 & 86.18 \\
\hline WS97.07 & HW2 & Indiana & 16 & РPT & 5 & 40.45 & 86.18 \\
\hline WS97.09 & $\mathrm{MT}$ & Indiana & 18 & LMF & 3 & 40.10 & 86.72 \\
\hline WS97.10 & LK1 & Indiana & 16 & PPT & 5 & 41.63 & 87.43 \\
\hline WS97.11 & LK2 & Indiana & 16 & EBFC & 5 & 41.63 & 87.43 \\
\hline WS97.14 & JK & Michigan & 16 & LMF & 3 & 42.30 & 84.28 \\
\hline WS97.16 & SC & Minnesota & 14 & EBFC & 5 & 42.65 & 82.53 \\
\hline WS97.17 & $\mathrm{HI}$ & Minnesota & 15 & EBFC & 5 & 42.50 & 82.57 \\
\hline WS97.19 & $\mathrm{CH}$ & Minnesota & 13 & РPT & 4 & 45.13 & 96.00 \\
\hline WS97.20 & $\mathrm{FL}$ & Minnesota & 16 & РPТ & 4 & 43.80 & 91.83 \\
\hline WS97.21 & $\mathrm{MO}$ & Minnesota & 17 & РPT & 5 & 46.20 & 94.42 \\
\hline WS97.22 & $\mathrm{RF}$ & Minnesota & 15 & EBFC & 6 & 44.53 & 95.08 \\
\hline WS97.29 & SP1 & Minnesota & 17 & EBFC & 4 & 44.32 & 93.93 \\
\hline WS97.30 & SP2 & Minnesota & 4 & EBFC & 4 & 44.30 & 93.97 \\
\hline WS97.31 & AN & Minnesota & 18 & РPT & 4 & 46.50 & 94.87 \\
\hline WS97.32 & AS1 & Minnesota & 19 & РPT & 4 & 46.38 & 94.90 \\
\hline WS97.33 & AS2 & Minnesota & 16 & EBFC & 4 & 46.37 & 94.98 \\
\hline WS97.34 & BT & New York & 10 & LMF & 3 & 42.98 & 78.18 \\
\hline WS97.35 & YC & Ohio & 16 & EBFC & 4 & 40.60 & 80.67 \\
\hline WS97.36 & SA & Ohio & 16 & EBFC & 5 & 40.55 & 80.67 \\
\hline WS97.37 & JN & Wisconsin & 14 & EBFC & 5 & 43.75 & 89.87 \\
\hline WS97.38 & CR & Wisconsin & 17 & EBFC & 5 & 44.67 & 91.83 \\
\hline WS97.45 & WP & Wisconsin & 16 & EBFC & 6 & 43.13 & 89.47 \\
\hline WS98.03 & SB3 & Wisconsin & 15 & LMF & 3 & 45.08 & 92.83 \\
\hline WS98.04 & SB4 & Wisconsin & 3 & EBFC & 5 & 45.08 & 92.83 \\
\hline WS98.05 & SB5 & Wisconsin & 12 & EBFC & 5 & 45.08 & 92.83 \\
\hline WS98.06 & BB1 & Wisconsin & 16 & LMF & 3 & 44.02 & 91.48 \\
\hline WS98.07 & BB2 & Wisconsin & 10 & EBFC & 5 & 44.02 & 92.48 \\
\hline WS98.13 & BV & Wisconsin & 16 & EBFC & 4 & 44.27 & 89.67 \\
\hline WS98.14 & $A R$ & Wisconsin & 17 & EBFO & 6 & 44.20 & 89.67 \\
\hline WS98.15 & $\mathrm{KP}$ & Wisconsin & 13 & EBFC & 4 & 43.93 & 88.78 \\
\hline WS98.16 & $\mathrm{RR} 1$ & Wisconsin & 17 & EBFC & 4 & 43.47 & 89.43 \\
\hline WS98.17 & RR2 & Wisconsin & 15 & РPT & 5 & 43.47 & 89.43 \\
\hline WS98.18 & IP1 & Wisconsin & 3 & LMF & 3 & 42.57 & 90.40 \\
\hline WS98.19 & IP2 & Wisconsin & 18 & EBFC & 4 & 42.57 & 90.40 \\
\hline WS98.20 & $\mathrm{BR} 1$ & Wisconsin & 12 & EBFC & 4 & 43.20 & 90.45 \\
\hline WS98.22 & BR3 & Wisconsin & 16 & EBFC & 4 & 43.20 & 90.45 \\
\hline WS98.26 & LC & Wisconsin & 6 & EBFC & 5 & 43.20 & 90.33 \\
\hline WS98.27 & WF & Wisconsin & 19 & EBFC & 5 & 42.78 & 88.30 \\
\hline WS98.28 & CP1 & Wisconsin & 18 & EBFC & 4 & 42.55 & 87.80 \\
\hline WS98.29 & CP2 & Wisconsin & 12 & EBFO & 6 & 42.53 & 87.80 \\
\hline WS98.30 & CP3 & Wisconsin & 14 & GPS & 4 & 42.52 & 87.80 \\
\hline WS98.31 & $\mathrm{KM}$ & Wisconsin & 18 & EBFC & 4 & 42.90 & 87.55 \\
\hline WS98.32 & $\mathrm{BL}$ & Wisconsin & 16 & EBFC & 4 & 42.85 & 88.63 \\
\hline WS98.33 & $\mathrm{PN}$ & Wisconsin & 13 & EBFO & 6 & 44.37 & 89.50 \\
\hline 'Blackwell' & & Oklahoma & 19 & EBFC & 5 & & \\
\hline 'Cave-In-Rock' & & Illinois & 16 & EBFC & 4 & & \\
\hline 'Pathfinder' & & Nebraska & 14 & LMF & 3 & & \\
\hline 'Shawnee' & & Illinois & 17 & EBFC & 5 & & \\
\hline 'Shelter' & & West Virginia & 5 & PPT & 5 & & \\
\hline 'Summer' & & Nebraska & 17 & EBFC & 6 & & \\
\hline 'Sunburst' & & South Dakota & 17 & EBFC & 6 & & \\
\hline 'Trailblazer' & & Nebraska & 18 & EBFC & 5 & & \\
\hline 'NE-HZ4-Syn1' & & - & 5 & EBFC & 4 & & \\
\hline 'NEearly-HYC3-HDC' & & Nebraska & 20 & EBFC & 4 & & \\
\hline 'NE28-HYC3-HDC2' & & Nebraska & 17 & EBFC & 4 & & \\
\hline
\end{tabular}

${ }^{\dagger}$ GPS $=$ Great Plains Steppe, PPT $=$ Prairie Parkland (Temperate), EBFC = Eastern Broadleaf Forest (Continental), and EBFO = Eastern Broadleaf Forest (Oceanic), and LMF = Laurentian Mixed Forest. 


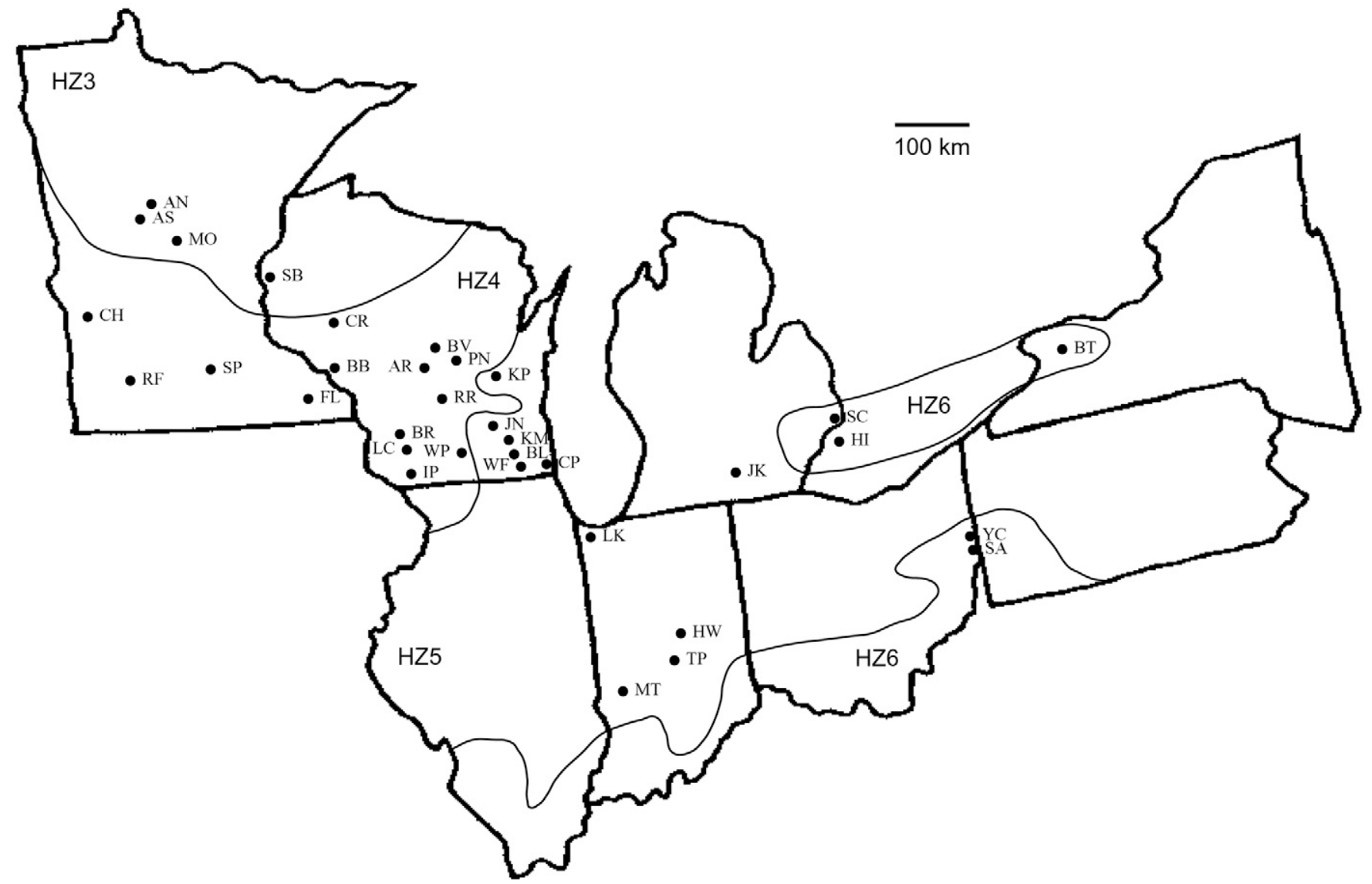

Figure 1. Albers equal-area projection of a portion of the north-central and northeastern USA, showing the location of 34 prairie remnant sites that were the source of 46 switchgrass accessions collected in 1997 and 1998. The site to the east of Michigan's Lower Peninsula $(\mathrm{HI})$ is on Hansen's Island in Lake St. Clair. The USDA hardiness zones (HZ) 3, 4, 5, and 6 are identified on the map (Cathey, 1990). All sites were located within the Eastern Broadleaf Forest (Continental) ecoregion, with the following exceptions: Sites CH and RF in the Prairie Parkland (Temperate) ecoregion; Sites AN, AS, MO, and SB in the Laurentian Mixed Forest ecoregion; and Sites SA and YC in the Eastern Broadleaf Forest (Oceanic) ecoregion (Bailey, 1998).

combinations were also estimated as the complement to Jaccard's similarity coefficient (Gower, 1972). Autocorrelations were computed from the $46 \times 46$ genetic distance matrix, representing seven geographic distance classes $(<5,5-50,51-100$, 101-200, 201-400, 401-800, and 801-1600 km). Autocorrelation coefficients were computed using the method of Smouse and Peakall (1999). First, the distance matrix was converted to a covariance matrix. Second, three incidence matrices were defined, one for each of the seven distance classes: incidence matrices consisted of 0 (absent from distance class) or 1 (present in distance class) for the off-diagonal elements and number of "hits" for each diagonal element (Smouse and Peakall, 1999). Third, the autocorrelation for distance class $h$, the combined correlation between all pairwise members of a distance class, was computed as

$$
r^{h}=\left(\sum_{i \neq j}^{N} X_{i j}^{h} C_{i j}\right)\left(\sum_{i=1}^{46} X_{i i}^{h} C_{i i}\right)
$$

where $i$ and $j$ are plant-number subscripts $(1, \ldots, 46)$ corresponding to matrix row and column numbers, $N$ is the total number of pairwise members of the genetic distance matrix, $X^{h}$ is the incidence matrix for the $h$ th distance class, and $C$ is the covariance matrix for RAPD marker data. Fourth, confidence intervals for autocorrelation coefficients of each distance class were computed from the empirical distribution of 1000 random permutations of the covariance matrix (Smouse and Peakall, 1999). Fifth, significance of the overall autocorrelation pattern for the seven distance classes was computed using the null distribution of the multivariate $T^{2}$ criterion, computed from the 1000 random permutations (Smouse and Peakall, 1999).

Coancestry coefficients $\left(F_{\mathrm{ST}}\right)$ were computed for all pairwise combinations of the 46 prairie remnant populations (Excoffier et al., 2005). Isolation of prairie-remnant populations by distance was investigated on two levels for each of the 46 prairie remnants. Estimates of $F_{\mathrm{ST}}$ were regressed on geographic distance for all pairs of populations, excluding those collected from the same site (geographic distance $<10 \mathrm{~km}$ ). Regressions were computed separately for each population paired with all others and geographic distance was expressed on a $\log _{10}$ scale (Slatkin, 1991). For each of the 10 sites with multiple populations, mean $F_{\text {ST }}$ was computed among the two or three populations within the site vs. the mean $F_{\mathrm{ST}}$ for all remaining pairs involving the populations at that site. Mean values of $F_{\mathrm{ST}}(<10 \mathrm{~km})$ vs. $F_{\mathrm{ST}}$ $(>10 \mathrm{~km})$ were compared by $t$-test.

\section{RESULTS}

Of 125 RAPD bands scored, eight were classified as monomorphic, having a marker frequency $>0.99$ or $<0.01$, and 
these were discarded from all statistical analyses. There were no markers unique to any single populations. One marker was common to only 15 populations, the smallest number among the remaining 117 markers; however, $95 \%$ of the markers were present in 30 or more of the 57 populations.

Analysis of molecular variance revealed significant marker variability between cultivars and prairie-remnant populations, but it explained $<1 \%$ of the total marker variation (Table 2). Furthermore, the structure of marker variability for cultivars and prairieremnant populations was identical. There was no marker variability associated with USDA hardiness zones or ecoregions for prairie-remnant populations (PRPs), or for the diverse regions of cultivar origin. There was significant marker variability among prairie-remnant populations within plant adaptation regions and among cultivars within origins, accounting for 32 and $29 \%$ of the total marker variability within these two groups. The $F_{\mathrm{ST}}$ values of 0.32 for prairie-remnant populations and 0.29 for cultivars indicated that there has been considerable gene flow among germplasm sources of each group. Most of the marker variability, $67 \%$ for prairie-remnant populations and $70 \%$ for cultivars, was observed among plants within populations (Table 2 ).

The lack of genetic differentiation between the two types of cultivars can be observed in Fig. 2. Distributions of plants show considerable overlap within regions, such as Hardiness Zone 6 in the eastern USA (the PRP-seedincrease cultivar Cave-in-Rock vs. the bred cultivar Shelter; Alderson and Sharp, 1994), Hardiness Zone 4 (the source-identified Northern Great Plains HZ4 gene pool vs. the bred cultivar Sunburst), and Hardiness Zone 6 in the Great Plains (the PRP-seed-increase cultivar Blackwell vs. the bred cultivars developed in Nebraska). These overlapping distributions also illustrate the lack of ecoregion or hardiness zone differentiation among cultivars. Similarly, average marker diversity was similar between cultivars such as Cave-in-Rock, derived as seed increases of prairie-remnant populations $(0.26 \pm 0.02)$, and cultivars derived by selection and breeding $(0.24 \pm 0.01)$.

The lack of ecoregion or hardiness zone differentiation for prairie-remnant populations is illustrated in Fig. 3. Despite this lack of molecular differentiation (Table 2), some structure exists among these prairie-remnant populations. Approximately $75 \%$ of the plants form a central core of plants with common genotypic profiles. Plants from the Eastern Broadleaf Forest (Continental) ecoregion and Hardiness Zone 4 (EBFC-4) form a horizontal axis along Dimension 1, while plants from EBFC-6 and Eastern Broadleaf Forest (Oceanic) ecoregion and Hardi- ness Zone 6 (EBFO-6) form a nearly vertical axis along Dimension 2. Finally, most of the plants from EBFC-5 form an axis from upper left to lower right, approximately $45^{\circ}$ offset from the other two axes. These axes illustrate a fundamental difference in the structural distribution of plants from these regions. Thus, while plants from these groups are not differentiated from each other, on the average, the distributions of their marker data are not strictly coincident with each other.

A direct comparison of Fig. 2 and 3 illustrates the huge overlapping distributions of the prairie-remnant populations and the cultivars. A relatively small number of plants from cultivars fell outside the distribution of the prairieremnant populations, 22 plants in the lower middle and three plants in the upper left of Fig. 2, representing four of the six cultivar groups. Thus, only $15 \%$ of the plants from the cultivars fell outside the range of the prairie-remnant populations. This does not represent a true differentiation between prairie remnants and cultivars, however, because the PRP-seed-increase cultivars and the bred cultivars were almost completely coincident in Fig. 2 . Thus, the bred cultivars did not contain any genotypes unique to this species or outside the range of prairie-remnant plants. Switchgrass cultivars could not be distinguished from prairie-remnant populations, either on the basis of genetic distance or genotypic structure.

Analysis of RAPD marker frequencies on a population basis provided similar results (Fig. 4). Populations originating from within a hardiness zone or ecoregion were spread throughout the cluster dendrogram, not showing any specific tendency to be clustered together. For example, the three populations from the eastern limit of this geographic region (populations SA and YC from Ohio and population BT from New York) were all highly unrelated to each other. Similarly, three populations from southeastern Michigan (JK, HI, and SC) were also very 


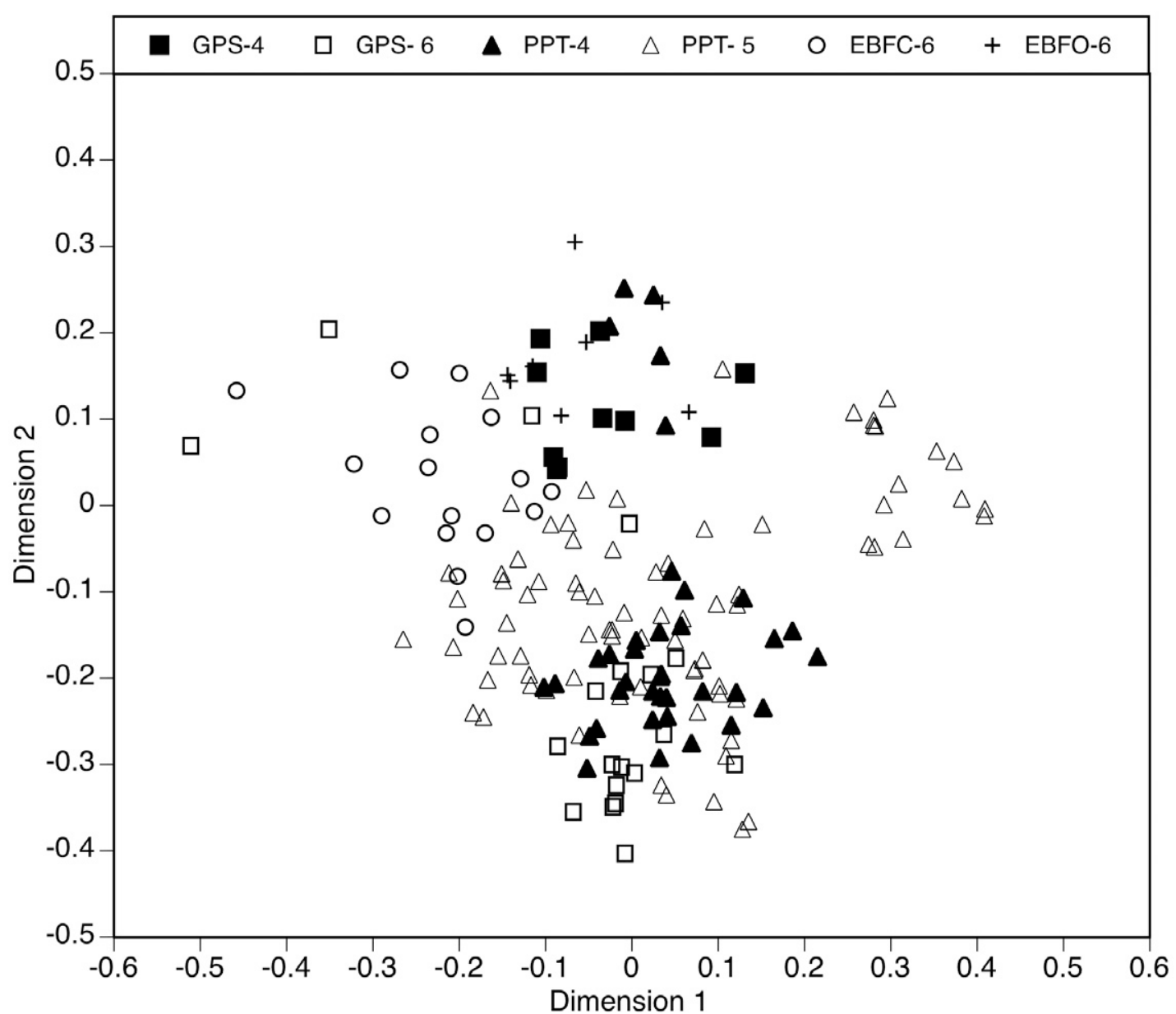

Figure 2. Scatterplot of the first two multidimensional scales for 165 plants representing 11 switchgrasscultivars, grouped by a combination of ecoregions (Bailey, 1998) and USDA hardiness zones (Cathey, 1990): PPT = Prairie Parkland (Temperate) ecoregion; EBFC = Eastern Broadleaf Forest (Continental) ecoregion; and EBFO = Eastern Broadleaf Forest (Oceanic) ecoregion. Numbers refer to USDA hardiness zones.

distant from each other. The cluster dendogram also illustrated the lack of geographic relationships among the cultivars, with cultivars from the Prairie Parkland (Temperate) ecoregion and Hardiness Zone 5 (PPT-5) spread throughout the dendrogram and a very close relationship between the geographically distant cultivars Shelter and NE-HZ4-Syn1.

There was a significant pattern of spatial variation among the 46 prairie-remnant populations, showing a decay in the autocorrelation with increasing geographic distance between populations (Fig. 5). This trend was statistically significant, even though the autocorrelations were extremely small in magnitude. The correlogram indicated that only pairs of populations originating $10 \mathrm{~km}$ or less apart had a significantly positive autocorrelation. The autocorrelation became significantly negative for all population pairs that were $>50 \mathrm{~km}$ distant from each other.

Using these results as a guide, the isolation-by-distance hypothesis was tested separately for populations that originated $<10 \mathrm{~km}$ from each other and those that originated $>10 \mathrm{~km}$ from each other (Table 3). Ten sites contained populations that originated $<10 \mathrm{~km}$ from each other (Table 3). For seven of these sites (HW, LK, AS, BB,
IP, BR, and $\mathrm{CP}$ ), estimated migration rates were significantly greater within sites than between the site and others $>10 \mathrm{~km}$ distant. On average for these seven sites, migration rates for $>10 \mathrm{~km}$ were $21 \%$ greater than for $<10 \mathrm{~km}$. Of the remaining sites, two had a significant difference in the opposite direction, with an estimated migration rate for $<10 \mathrm{~km} 9 \%$ greater than for $>10 \mathrm{~km}$. Only three sites $\left(\mathrm{CH}, \mathrm{MO}\right.$, and $\mathrm{RF}$ ) had significant regressions of $F_{\mathrm{ST}}$ on geographic distance (Fig. 6).

\section{DISCUSSION}

Population structure was similar for prairie-remnant populations and cultivars of switchgrass, with little or no marker variation associated with geographic zones. Prairie-remnant populations of switchgrass from this portion of North America varied in marker frequencies, but generally not in the presence or absence of individual markers. For other cross-pollinated perennial grasses, within-population marker variability ranges from 65 to $95 \%$ of the total marker variability (Gustafson et al., 1999, 2004; Huff et al., 1993, 1998; Kölliker et al., 1999; Ubi et al., 2003; Xu et al., 1994). These results confirm that the genotypic structure of switchgrass populations falls within the range observed 


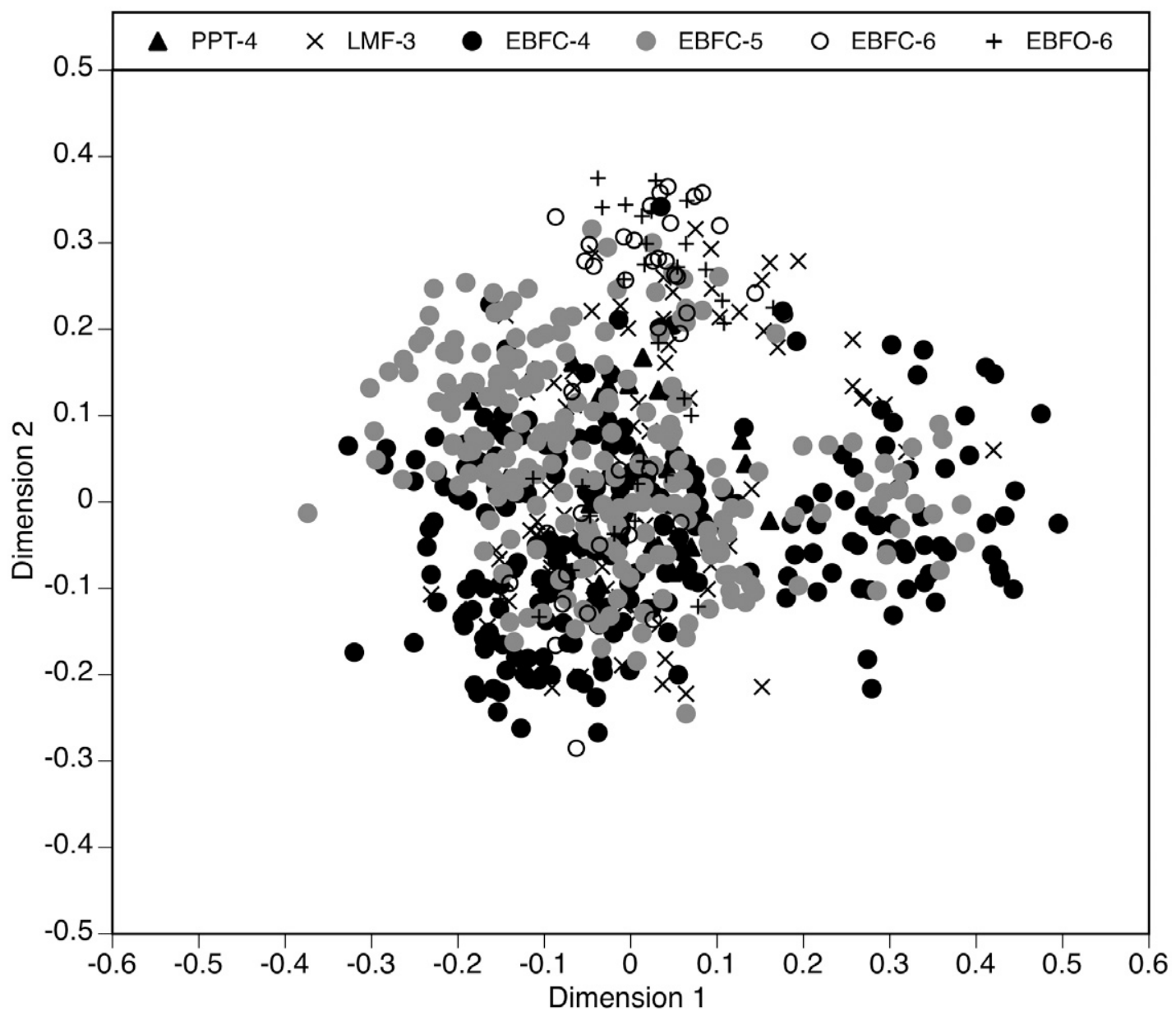

Figure 3. Scatterplot of the first two multidimensional scales for 653 switchgrass plants representing six geographical areas defined by a combination of ecoregions (Bailey, 1998) and USDA hardiness zones (Cathey, 1990): PPT = Prairie Parkland (Temperate) ecoregion; LMF $=$ Laurentian Mixed Forest ecoregion; EBFC = Eastern Broadleaf Forest (Continental) ecoregion; and EBFO = Eastern Broadleaf Forest (Oceanic) ecoregion. Numbers refer to USDA hardiness zones.

for other cross-pollinated grasses, albeit at the low end of the distribution. Population differentiation of both switchgrass prairie-remnant populations and cultivars appears to be slightly higher than that observed for most other crosspollinated grasses. This includes big bluestem (Andropogon gerardii Vitman) and Indian grass [Sorghastrum nutans (L.) Nash], the other two dominant graminoids of the tallgrass prairie, for which populations accounted for $12 \%$ of the RAPD marker variability (Gustafson et al., 2004).

The limited breeding history of switchgrass has not narrowed the genetic variability among or within cultivars, as indicated by the similar levels of within-population marker variability for these three groups. Similarly, average marker diversity was approximately equal for bred cultivars and prairie-remnant populations of both big bluestem and Indian grass (Gustafson et al., 2004). Marker diversity was also similar within prairie-remnant populations from prairies of vastly different size, indicating that small prairie remnants can be valuable sources of genetic diversity (Gustafson et al., 2004).

The lack of marker variation between the three groups (bred cultivars, PRP-seed-increase cultivars, and prairie- remnant populations) indicated little genetic differentiation among these groups. To many people, this result may seem at odds with the concept of "improved" cultivars. It begs the question, how can an "improved" cultivar, one that has a supposed agronomic advantage over natural germplasm, be genetically undifferentiated from natural germplasm? Nevertheless, this observation conforms to plant breeding theory that indicates expectations of relatively small changes in phenotype and gene frequencies associated with a very small number of selection cycles (Vogel and Pedersen, 1993). The lack of genetic differentiation among prairie remnant populations, PRP-seed-increase cultivars, and bred cultivars can be attributed to several factors.

1. No more than two or three generations or cycles of selection have occurred in the selection and breeding of the bred cultivars, limiting the potential for genetic differentiation of this group (Alderson and Sharp, 1994). For species with a long breeding history, there is a clear genetic differentiation between cultivars and natural populations (Kölliker et al., 1998).

2. Agronomic selection to develop new cultivars acts on large numbers of loci that regulate several quantitative 


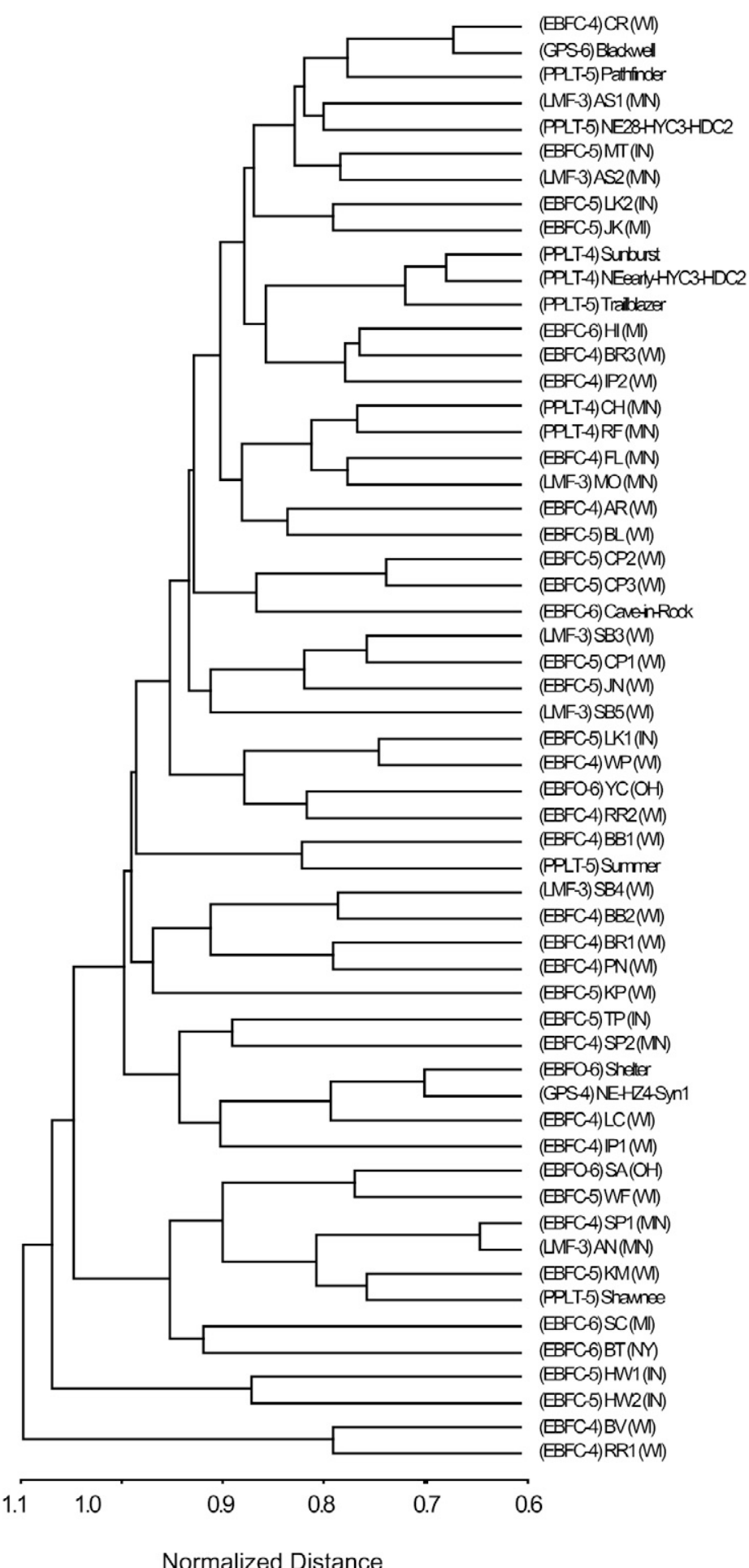

Normalized Distance

Figure 4. Cluster dendrogram of 57 switchgrass populations and cultivars, based on unweighted pair group method with arithmetic mean (UPGMA) clustering of 117 DNA markers.

traits (Falconer and Mackay, 1996). Changes occur in the frequency of individual alleles, not in the presence or absence of alleles, and these accrue very slowly with time and generations (Falconer and Mackay, 1996). Many of the bred cultivars were developed by selection for several plant traits, resulting in relatively mild selection pressures for any individual trait, thus

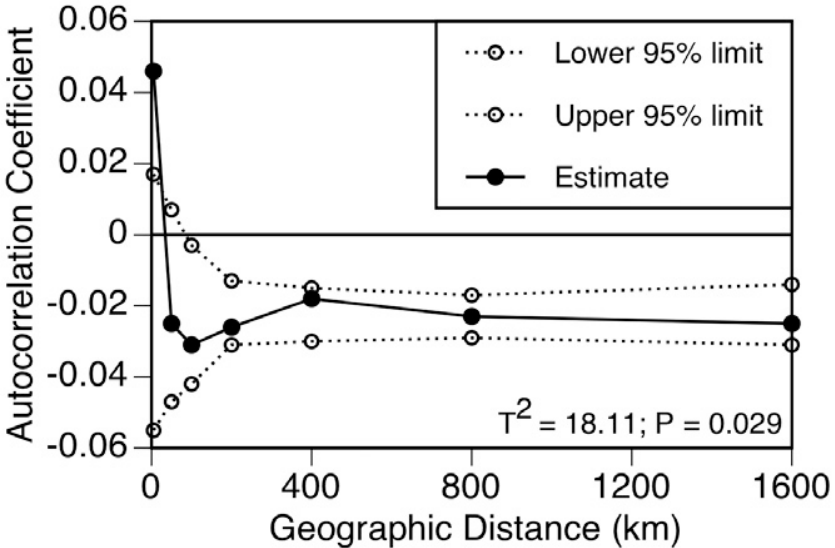

Figure 5. Correlogram of autocorrelation coefficients plotted against geographic distance between paired prairie-remnant switchgrass populations. $T^{2}=$ test criterion for the overall pattern of autocorrelation as a function of geographic distance.

limiting the potential for large or biologically significant shifts in allele frequencies (Falconer and Mackay, 1996). Furthermore, gains from selection for quantitative traits are generally very small, typically resulting in changes of $<2 \%$ per cycle of selection for any given trait (Vogel and Pedersen, 1993; Vogel, 2004). The accumulated multigeneration changes made by breeding may be economically significant for agronomic traits but they may have little or no effect on morphological or fitness traits. This has been clearly demonstrated in a multilocation, multiple-year study with switchgrass in Wisconsin (Casler, 2005). Differences between cultivars and prairie-remnant populations for fitness or morphological traits were small and inconsistent (Casler, 2005), indicating limited phenotypic divergence between these groups.

3. The polyploid genome of switchgrass, ranging from $4 \times$ to $10 \times$ (Vogel, 2004), captures huge amounts of genetic variability due to a higher frequency of heterozygotes than for diploid organisms in randommating equilibrium (Gallais, 2003, p. 186). Genetic recombination constantly creates new gene combinations, releasing new genetic variability with each generation and counterbalancing losses of genetic variability due to either selection or drift.

4. Switchgrass has a self-incompatibility system that favors cross-pollination (Martinez-Reyna and Vogel, 2002), maintaining a higher-than-expected frequency of heterozygotes and accelerating the breakup of linkage blocks (Hartl and Clark, 1989). Self-incompatibility systems generally maintain 3 to 10 times more genetic variability within populations than among populations (Gustafson et al., 1999, 2004; Huff et al., 1993, 1998; Kölliker et al., 1999; Ubi et al., 2003; Xu et al., 1994).

5. Finally, molecular markers are not necessarily associated with agronomic traits. Changes in 
agronomic traits may be associated with a limited number of molecular markers (Diaby and Casler, 2005), but most markers appear to be selectively neutral or generally unrelated to the selection criteria (Stuber et al., 1980). Small changes in agronomic traits, sufficient to represent a statistical or biological improvement in agricultural fitness, may be completely unrelated to changes in DNA markers or marker profiles, probably reflecting relatively small changes in allele frequencies at relatively few loci.

The results shown in Table 3 and Fig. 6 provide marginal support for the isolation-by-distance hypothesis (Slatkin, 1993). For a small number of sites, there was evidence of greater gene flow between populations within a site $(<10 \mathrm{~km})$ vs. populations at sites $>10 \mathrm{~km}$ apart. For an even smaller number of sites, there was evidence of a gradual decline in gene flow with increasing distance between sites. In the latter case, all three sites (CH, RF, and $\mathrm{MO}$ ) were in western Minnesota, at the western margin of the geographic inference range for this study (Fig. 1). Thus, isolation by distance on the landscape scale was unidirectional, probably resulting from the effects of prevailing westerly winds on pollen transmission rates across the landscape. Conversely, sites located more centrally or easterly within the study area probably showed no evidence of isolation by distance due to reduced potential for differential pollen transmission rates in an easterly direction.

Although there was slight and statistically significant evidence for spatial variation and for isolation by distance, these effects were extremely small and restricted to a small number of prairie-remnant sites. These small effects, the lack of clear regional differentiation, and the structure of genetic variability among these populations all support the existence of a highly fragmented, remnant population of switchgrass in the north-central and eastern USA (Ericksson, 1996). Local populations of switchgrass have been subject to extinction largely by the human-driven process of plowing prairies to create cropland (Risser et al., 1981). This activity seems to have largely come to a halt, with preservation of the few remaining prairie remnants under the ownership, control, or custodianship of a wide range of public and private conservation and recreation organizations (Casler, 2005; Hopkins et al., 1995). Colonization occurs largely as a human-driven process of harvesting seed from prairie remnants and using this seed as germplasm for prairie restoration (Jones, 2003; Jones and Johnson, 1998). Finally, this study provides evidence of migration between prairie-remnant populations, suggesting that migration occurs across a large regional scale, as indicated by highly overlapping distributions, lack of biologically significant spatial differentiation, and the relatively low importance of geographic distance as an isola-

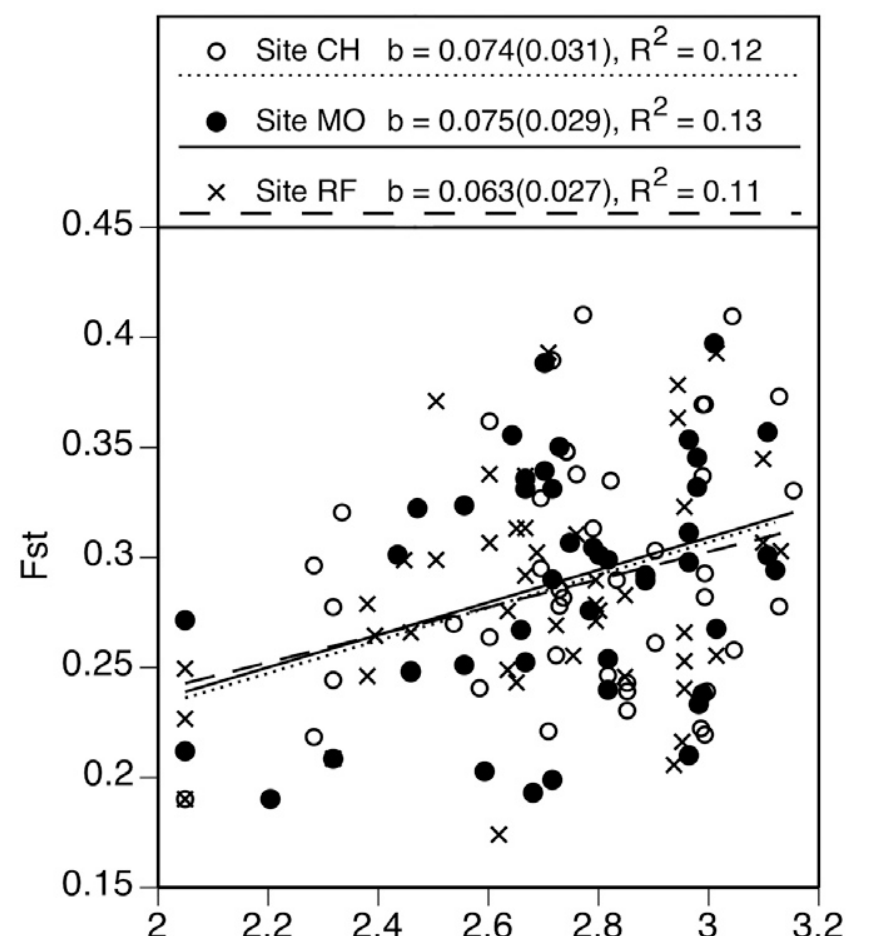

Figure 6. Scatterplots and linear regressions of coancestry coefficients $\left(F_{\mathrm{ST}}\right)$ vs. geographic distance for switchgrass prairieremnant populations from three sites in western Minnesota paired with populations from the remaining 33 sites.

tion mechanism. Migration may result from natural forces such as wind-facilitated pollen flow or animal-facilitated seed dispersal, or human forces such agricultural or restoration plantings.

Selection, drift, and migration have all probably been major forces driving the observed structure of this remnant population. Historically, migration may be the most important of these forces, having acted to homogenize the population across landscapes, minimizing genetic differentiation on a regional scale. Migration was probably 
more frequent when the tallgrass prairie ecosystem was more broadly abundant across the central and eastern USA, facilitating gene flow by pollen movement across a more or less continuous ecosystem. The lack of strong evidence for isolation by distance suggests that migration is no longer of major importance in regulating the population structure of switchgrass in this region.

Habitat fragmentation has probably resulted in population differentiation through the processes of drift and selection (Hanski, 1991; Husband and Barrett, 1996). Local differentiation, which accounts for all population differentiation observed in this study, may arise from chance events known as genetic drift, which results from small founder populations and habitat fragmentation (Falconer and Mackay, 1996). Drift may have occurred in members of the tallgrass prairie as this ecosystem advanced north following the Pleistocene glaciation. Population differentiation also may arise from selection for adaptation to specific environmental factors, such as soil type, habitat, and coexisting vegetation (Bradshaw, 1972; Linhart and Grant, 1996). Because of the broad adaptation range of switchgrass ecotypes and cultivars (Casler, 2005; Casler et al., 2004; Hopkins et al., 1995), selection may be of secondary importance in creating local differentiation. Selection has acted on a large regional scale, differentiating populations for flowering time, photoperiodism, cold tolerance, and heat tolerance, strongly on a latitudinal gradient and weakly on a longitudinal gradient (Casler, 2005; Casler et al., 2004; McMillian, 1959, 1965; McMillian and Weiler, 1959).

Results from both big bluestem and Indian grass suggest a similar structure of a remnant population. Although the number of populations and the sampling area was more limited than for our study of switchgrass, there was little spatial variation on a relatively narrow landscape scale, but some population differentiation was observed between populations from Illinois vs. the Great Plains (Gustafson et al., 1999, 2004). These three species share numerous life-history traits, as well as a long evolutionary history, suggesting that evolutionary forces and habitat fragmentation have probably had similar effects on the structure of prairie-remnant populations of all three species.

\section{CONCLUSIONS}

While there is a clear consensus that adapted germplasm is preferable for conservation, restoration, and breeding new cultivars, there has been little effort to define specific localities or, preferably, adaptation regions to be used in defining useful gene pools (Jones and Johnson, 1998; Knapp and Rice, 1994). Plant adaptation regions (PARs), combining hardiness zones with plant ecoregions (Vogel et al., 2005), provide a mechanistic framework to identify gene pool localities for conservation, restoration, and breeding efforts. The USDA hardiness zones are defined largely by gradients of $5.5^{\circ} \mathrm{C}$ (Cathey, 1990), creating a system of survival and adaptation zones associated with phenotypic variability for adaptation traits such as flowering time, photoperiodism, cold tolerance, and heat tolerance (Casler et al., 2004). Bailey's ecoregions are defined by presettlement dominant successional vegetation classes, which are correlated with major soil taxa (Bailey, 1998). Natural selection of populations in contrasting environments contributes significantly to ecological differentiation within species (Bradshaw, 1972; Linhart and Grant, 1996), driven partly by soil, climate, and photoperiod factors. Digitization of both USDA hardiness zone and Bailey's ecoregion boundaries using geographic information system software allows additional prairie-remnant populations to be easily classified, providing a distinct advantage to the PAR system (Vogel et al., 2005). Bailey's ecoregion classification system was the best of five systems investigated by Steiner and Greene (1996) as a regional germplasm classification system. The PAR system of Vogel et al. (2005) is comparable to the "seed zone" system for conifers of the western USA (Johnson et al., 2004).

Plant adaptation regions can be used in conjunction with Jones' (2003) proposal of primary and secondary restoration gene pools (RGPs), which are applicable for conservation, restoration, or breeding. Jones (2003) defined the primary RGP as the target population itself or germplasm connected to it via pollen flow or seed dispersal. In many restoration situations, the target population itself doesn't exist, because of severe or long-term disturbance or habitat loss (e.g., loss of the tallgrass prairie ecosystem to agriculture). Our results for switchgrass suggest that any prairie-remnant populations within the PAR can be used to represent the primary gene pool of that PAR. Restriction of a RGP to a narrowly defined region or habitat, as suggested by some researchers (Kitzmiller, 1990; Linhart, 1995; Millar and Libby, 1991), is unnecessarily restrictive for switchgrass. Because most of the genetic variability occurs within populations, a relatively small number of collection sites are sufficient to maintain genetic variability of the gene pool. A multiple-origin polycross would provide a mechanism to create a source-identified population, equally represented by any number of collection sites within the PAR (Jones, 2003). A polycross of two genetically heterogeneous local populations may be sufficient to maintain genetic diversity of a restoration gene pool (Gustafson et al., 2002). Standardized, commercial seed production practices should be used to increase seed in a representative environment within the PAR, minimizing the potential for selection (Vogel, 2004). Seed orchards should be sufficiently large to minimize genetic drift and provide a source of seed adequate for the region's conservation and restoration needs (Knapp and Rice, 1994). Partnerships between agencies responsible for conservation and restoration, state crop improvement organiza- 
tions, and private organizations with experience in seed production may prove valuable in developing an affordable and reliable source of high-quality seed for restoration.

The results of this study indicate that prior, current, or future use of switchgrass cultivars for restoration purposes will not contaminate, pollute, swamp, or disrupt local gene pools. Plant genotypes contained within cultivars are not unique to these cultivars, but are broadly representative of switchgrass germplasm from prairie-remnant populations within the northern and central USA. There appear to be no "non-native genes" in switchgrass cultivars, as Millar and Libby (1989) suggested for non-native Pinus muricata D. Don of unknown origin. Although switchgrass cultivars could also be included in multiple-origin polycrosses used as RGPs (Jones, 2003), the use of bred cultivars is not necessary for this purpose. Because of the huge amount of within-population genetic variability in this species, a relatively small number of source-identified populations should prove sufficient to represent any given PAR. There is, however, no reason to exclude PRP-seedincrease cultivars, as they do not represent any form of breeding, selection, or human-based improvement. Those who criticize the use of cultivars for restoration purposes should recognize the dual use of this term and the fact that some cultivars are no different than any source-identified prairie-remnant population. The results of this study indicate that currently available cultivars developed by breeding have not been altered to the extent that they should be arbitrarily excluded from conservation plantings, particularly if they represent the local PAR and are the most readily available source of switchgrass seed.

An unselected or natural-track RGP can be released under any one of four germplasm classes: source identified, selected, tested, or cultivar (Jones and Johnson, 1998; Rogers and Montalvo, 2004). In this case, the "selected" category refers to selection among ecotypes, but no intentional selection within ecotypes. It should be pointed out that natural selection within an RGP is not necessarily undesirable, because it may allow a genetically broad RGP to adapt itself more favorably to a wide range of sites (Jones, 2003; Jones and Johnson, 1998; Kitzmiller, 1990). The "cultivar" category is identified as "natural track" to separate it from bred or manipulated cultivars, but this distinction is often lost during the seed multiplication and commercialization process (Alderson and Sharp, 1994).

Finally, it should be recognized that the PAR system has some limitations. Any environmental classification system based on discrete boundaries cannot take into account all sources of environmental variability that drive plant adaptation mechanisms. For example, highly disturbed sites, such as mine spoils, smelters, refineries, saline soils, or abandoned military sites, may require the use of special germplasm selected for tolerances to specific toxins or other physical or environmental factors but otherwise representing the local gene pool. Because genes for tolerance to many such factors exist at very low levels within many natural populations (Macnair, 1991), this may require little more than some human-facilitated natural selection to concentrate the genes for such tolerances within the local PAR gene pool without sacrificing genetic variability (Casler et al., 1996). In some situations, however, such as devastating disease epiphytotics, intensive selection for pest resistance may be an essential step in creating a useful RGP (Krakowski et al., 2003). Additionally, variation for soil type, elevation, and collateral vegetation may be significant factors reducing the size of effective PARs for defining restoration gene pools (Millar and Libby, 1991). These factors may lead to the need for multiple restoration gene pools for a given plant adaptation region. This and other potential issues in the use of natural germplasm for restoration should be more comprehensively addressed by field tests with proper experimental designs.

\section{Acknowledgments}

We thank the following individuals for collecting switchgrass seed from prairie-remnant sites and for providing provenance information on local sites: Valerie Berglund-Garcia, Bob Berkemeier, Barry Bortner, Steve Breaker, William Bronder, Mitch Cattrell, Rebecca Cifaldi, Don Cree, Dave Dortman, Rick Grooters, Russ Haas, Bob Hanson, Glenn Hartman, Kim Herman, Lee Johnson, Doug Keene, Bruce Knapp, Paul Labus, Nicole McClain, Dan McGuckin, Chris Newell, Julius Pigott, Roger Powell, Mary Jane Reetz, Dennis Reimers, Ivan Reinke, David Stanley, Steve Smith, Ed Stuff, Walter Summers, David Walter, and Greg Wheeler. We also thank Dave Burgdorf and Phil Koch, USDA-NRCS, Rose Lake Plant Materials Center, for organizing the aforementioned individuals to collect the accessions used in this study. We thank Andy Beal for his tireless and dedicated efforts to collect seed from numerous prairie remnants in Wisconsin and Mark Martin, Wisconsin Department of Natural Resources, for assistance in obtaining permission to collect switchgrass seed throughout Wisconsin. We thank Lee Gunter, Oak Ridge National Laboratory, for valuable assistance in developing RAPD marker techniques and identifying RAPD primers. This research was funded in part by Specific Cooperative Agreement 58-5440-7-123 between the U.S. Department of Agriculture, Agricultural Research Service (USDA-ARS) and the University of Wisconsin-Madison, which was a component of the U.S. Department of Energy, Oak Ridge National Laboratory and USDA-ARS Interagency Agreement under Contract DE-A105 900R21954, and by the College of Agricultural and Life Sciences, University of Wisconsin-Madison. Mention of a trademark does not imply endorsement of a product over any other product by the USDA-ARS or the University of Wisconsin.

\section{References}

Alderson, J., and W.C. Sharp. 1994. Grass varieties in the United States. Agric. Handbk. 170 (Revised). U.S. Gov. Print. Office, Washington, DC

Bailey, R.G. 1998. Ecoregions: The ecosystem geography of the oceans and continents. Springer-Verlag, New York. 
Bradshaw, A.D. 1972. Some of the evolutionary consequences of being a plant. Evol. Biol. 5:25-47.

Casler, M.D. 2005. Ecotypic variation among switchgrass populations from the northern USA. Crop Sci. 45:388-398.

Casler, M.D., J.F. Pedersen, G.C. Eizenga, and S.D. Stratton. 1996. Germplasm and cultivar development. p. 413-469. In L.E. Moser et al. (ed.) Cool-season forage grasses. Agron. Monogr. 34. ASA, CSSA, and SSSA, Madison, WI.

Casler, M.D., K.P. Vogel, C.M. Taliferro, and R.L. Wynia. 2004. Latitudinal adaptation of switchgrass populations. Crop Sci. 44:293-303.

Cathey, H.M. 1990. USDA Plant hardiness zone map. USDA Misc. Publ. 1475. Available at www.usna.usda.gov/Hardzone/ushzmap.html (verified 20 June 2007). U.S. Natl. Arboretum, Washington, DC.

Clewell, A., and J.P. Rieger. 1997. What practitioners need from restoration ecologists. Restor. Ecol. 35:350-354.

Diaby, M., and M.D. Casler. 2005. RAPD marker variation among divergent selections for fiber concentration in smooth bromegrass. Crop Sci. 45:27-35.

Ericksson, O. 1996. Regional dynamics of plants: A review of evidence for remnant, source-sink, and metapopulations. Oikos 77:248-258

Excoffier, L., G. Laval, and S. Schneider. 2005. Arlequin version 3.0: An integrated software package for population genetics data analysis. Evol. Bioinform. Online 1:47-50.

Falconer, D.S., and T.F.C. Mackay. 1996. An introduction to quantitative genetics. 4th ed. Longman House, Burnt Mill, UK.

Gallais, A. 2003. Quantitative genetics and breeding methods in autopolyploid plants. Inst. Natl. de la Recherche Agron., Paris.

Gower, J.C. 1972. Measures of taxonomic distance and their analysis. p. 1-24. In J.S. Weiner and J. Huizinga (ed.) The assessment of population affinities in man. Clarendon Press, Oxford, England.

Gustafson, D.J., D.J. Gibson, and D.L. Nickrent. 1999. Random amplified polymorphic DNA variation among remnant big bluestem (Andropogon gerardii Vitman) populations from Arkansas' Grand Prairie. Mol. Ecol. 8:1693-1701.

Gustafson, D.J., D.J. Gibson, and D.L. Nickrent. 2002. Genetic diversity and competitive abilities of Dalea purpurea (Fabaceae) from remnant and restored grasslands. Int. J. Plant Sci. 163:979-990.

Gustafson, D.J., D.J. Gibson, and D.L. Nickrent. 2004. Conservation genetics of two co-dominant grass species in an endangered grassland ecosystem. J. Appl. Ecol. 41:389-397.

Hanski, I. 1991. Single-species metapopulation dynamics. p. 17-38. In M. Gilpin and I. Hanski (ed.) Metapopulation dynamics: Empirical and theoretical investigations. Academic Press, London.

Hartl, D.L., and A.G. Clark. 1989. Principles of population genetics. 2nd ed. Sinauer Assoc., Sunderland, MA.

Hopkins, A.A., K.P. Vogel, K.J. Moore, K.D. Johnson, and I.T. Carlson. 1995. Genotypic variability and genotype $\times$ environment interactions among switchgrass accessions from the midwestern USA. Crop Sci. 35:565-571.

Huff, D.R., R. Peakall, and P.E. Smouse. 1993. [Buchloë dactyloides (Nutt.) Engelm.] RAPD variation within and among natural populations of outcrossing buffalograss. Theor. Appl. Genet. 86:927-934.

Huff, D.R., J.A. Quinn, B. Higgins, and A.J. Palazzo. 1998. Random amplified polymorphic DNA (RAPD) variation among native little bluestem [Schizachyrium scoparium (Michx.) Nash] populations from sites of high and low fertility in forest and grassland biomes. Mol. Ecol. 7:1591-1597.

Husband, B.C., and S.C.H. Barrett. 1996. A metapopulation perspective in plant population biology. J. Ecol. 84:461-469.

Johns, M.A., P.W. Skroch, J. Nienhuis, P. Hinrichsen, G. Bascur, and C. Muñoz-Schick. 1997. Gene pool classification of common bean landraces from Chile based on RAPD and morphological data. Crop Sci. 37:605-613.

Johnson, G.R., F.C. Sorensen, J.B. St. Clair, and R.C. Cronn. 2004. Pacific Northwest forest tree seed zones: A template for native plants? Native Plants J. 5:131-140.

Jones, T.A. 2003. The restoration gene pool concept: Beyond the native versus non-native debate. Restor. Ecol. 11:281-290.

Jones, T.A., and D.A. Johnson. 1998. Integrating genetic concepts into planning rangeland seedings. J. Range Manage. 51:594606.

Kitzmiller, J.H. 1990. Managing genetic diversity in a tree improvement program. For. Ecol. Manage. 35:131-149.

Knapp, E.E., and K.J. Rice. 1994. Starting from seed: Genetic issues in using native grasses for restoration. Restor. Manage. Notes 12:40-40-45.

Kölliker, R., F.J. Stadelmann, B. Reidy, and J. Nösberger. 1998. Fertilization and defoliation frequency affect genetic diversity of Festuca pratensis Huds. in permanent grasslands. Mol. Ecol. 7:1557-1567.

Kölliker, R., F.J. Stadelmann, B. Reidy, and J. Nösberger. 1999. Genetic variability of forage grass cultivars: A comparison of Festuca pratensis Huds., Lolium perenne L., and Dactylis glomerata L. Euphytica 106:261-270.

Krakowski, J., S.N. Aitken, and Y.A. El-Kassaby. 2003. Inbreeding and conservation genetics in whitebark pine. Conserv. Genet. 4:581-593.

Lesica, P., and F.W. Allendorf. 1999. Ecological genetics and the restoration of plant communities: Mix or match? Restor. Ecol. 7:42-50.

Linhart, Y.B. 1995. Restoration, revegetation, and the importance of genetic and evolutionary perspectives. p. 271-287. In B.A Roundy et al. (ed.) Proc. Wildland Shrub and Arid Land Restoration Symp., Las Vegas, NV. 19-21 Oct. 1993. Gen. Tech. Rep. INT-GTR-315. U.S. Forest Service, Ogden, UT.

Linhart, Y.B., and M.C. Grant. 1996. Evolutionary significance of local genetic differentiation in plants. Annu. Rev. Ecol. Syst. 27:237-277.

Macnair, M.R. 1991. Why the evolution of resistance to anthropogenic toxins normally involves major gene changes: The limits to natural selection. Genetica 84:213-219.

Martinez-Reyna, J.M., and K.P. Vogel. 2002. Incompatability systems in switchgrass. Crop Sci. 42:1800-1805.

McMillian, C. 1959. The role of ecotypic variation in the distribution of the central grassland of North America. Ecol. Monogr. 29:285-308.

McMillian, C. 1965. Ecotypic differences with four North American prairie grasses: II. Behavioral variation with transplanted community fractions. Am. J. Bot. 52:55-65.

McMillian, C., and J. Weiler. 1959. Cytogeography of Panicum virgatum in central North America. Am. J. Bot. 46:590-593.

Millar, C.I., and W.J. Libby. 1989. Disneyland or native ecosystem: Genetics and the restorationist. Restor. Manage. Notes 7:18-24.

Millar, C.I., and W.J. Libby. 1991. Strategies for conserving clinal, ecotypic, and disjunct population diversity in widespread species. p. 149-170. In D.A. Falk and K.E. Hoisington (ed.) Genetics and conservation of rare plants. Oxford Univ. Press, New York. 
Montalvo, A.M., S.L. Williams, K.J. Rice, S.L. Buchmann, C. Cory, S.N. Handel, G.P. Nabhan, R. Primack, and R.H. Robichaux. 1997. Restoration biology: A population biology perspective. Restor. Ecol. 5:277-290.

Nei, M. 1987. Molecular evolutionary genetics. Columbia Univ. Press, New York.

Risser, P.G., E.C. Birney, H.D. Blocker, S.W. May, W.J. Parton, and J.A. Wiens. 1981. The true prairie ecosystem. Hutchinson Ross, Stroudsburg, PA.

Rogers, D.L., and A.M. Montalvo. 2004. Genetically appropriate choices for plant materials to maintain biological diversity. Available at www.fs.fed.us/r2/publications/botany/plantgenetics.pdf (verified 20 June 2007). U.S> For. Serv., Lakewood, CO.

SAS Institute. 1999. SAS/STAT user's guide. Version 7-1.3415. SAS Inst., Cary, NC.

Slatkin, M. 1991. Inbreeding coefficients and coalescence times. Genet. Res. 58:167-175.

Slatkin, M. 1993. Isolation by distance in equilibrium and nonequilibrium populations. Evolution 47:264-279.

Smouse, P.E., and R. Peakall. 1999. Spatial autocorrelation analysis of individual multiallele and multilocus genetic structure. Heredity 82:561-573.

Steiner, J.J., and S.L. Greene. 1996. Proposed ecological descrip- tors and their utility for plant germplasm collectors. Crop Sci. 36:439-451.

Stubbendieck, J., S.L. Hatch, and C.H. Butterfield. 1991. North American range plants. Univ. of Nebraska Press, Lincoln.

Stuber, C.W., R.H. Moll, M.M. Goodman, H.E. Schaffer, and B.S. Weir. 1980. Allozyme frequency changes associated with selection for increased grain yield in maize (Zea mays L.). Genetics 95:225-236.

Ubi, B.E., R. Kölliker, M. Fujimori, and T. Komatsu. 2003. Genetic diversity in diploid cultivars of rhodesgrass determined on the basis of amplified fragment length polymorphism markers. Crop Sci. 43:1516-1522.

Vogel, K.P. 2004. Switchgrass. p. 561-588. In L.E. Moser et al. (ed.) Warm-season $\left(\mathrm{C}_{4}\right)$ grasses. Agron. Monogr. 45. ASA, CSSA, and SSSA, Madison, WI.

Vogel, K.P., and J.F. Pedersen. 1993. Breeding systems for crosspollinated perennial grasses. Plant Breed. Rev. 11:251-274.

Vogel, K.P., M.R. Schmer, and R.B. Mitchell. 2005. Plant adaptation regions: Ecological and climatic classification of plant materials. Range. Ecol. Manage. 58:315-319.

Xu, W.W., D.A. Sleper, and G.F. Krause. 1994. Genetic diversity of tall fescue germplasm based on RFLPs. Crop Sci. 34:246-252. 